\title{
Pelatihan Teknologi Sistem Informasi bagi Nelayan pada Masa Covid-19 di Era Digital
}

\author{
Ismail Ismail*1 Endang Gunaisah², M. Ali Ulat ${ }^{3}$, Muhfizar Muhfizar ${ }^{4}$, Hendra Poltak ${ }^{5}$. \\ 1,2,3Program Studi Teknik Penangkapan Ikan, ${ }^{4}$ Program Studi Mekanisasi Perikanan, ${ }^{5}$ Program Studi \\ Teknik Budidaya Perikanan, Politeknik Kelautan dan Perikanan Sorong \\ *e-mail: ismailabdullahumum@gmail.com ${ }^{1}$, gunaisah2109@gmail.com ${ }^{2}$, alipoltek12@gmail.com³ \\ muhfizar@gmail.com ${ }^{4}$, hendra.poltak@polikpsorong.ac.id ${ }^{5}$
}

\begin{abstract}
Information system technology is changing so fast connecting a world without limits. The ability to access unlimited information resources can be a medium to improve the welfare and independence of all groups of people, including the fishermen group. However, the low level of human resources is an inhibiting factor in understanding information technology so there are limitations in accessing new knowledge to improve their welfare. Community service provides solutions for partners during the Covid-19 period in the digital age through training delivered through conventional and online and mentoring tailored to biodata and initial observations. Training and intervention through mentoring provided capacity building for the Fishermen group in District Maladum Mes based on 79\% post test results and training output achieved in the form of all partners having e-mail accounts, social media accounts, and video conference accounts.
\end{abstract}

Keywords: Information Systems, Zoom Meeting, Fishermen, Human Resource

\begin{abstract}
Abstrak
Teknologi sistem informasi berubah begitu cepat mengkoneksikan dunia tanpa batas. Kemampuan mengakses sumber daya informasi yang tanpa batas ini dapat menjadi media untuk meningkatkan kesejahteraan dan kemandirian bagi semua kelompok masyarakat, tidak terkecuali kelompok nelayan. Namun, rendahnya SDM menjadi faktor penghambat dalam memahami teknologi informasi sehingga ada keterbatasan mengakses pengetahuan-pengetahuan baru untuk meningkatkan kesejahteraannya. Pengabdian masyarakat memberikan solusi bagi mitra pada masa covid-19 di Era Digital melalui pelatihan yang disampaikan secara konvensional maupun daring dan pendampingan disesuaikan dengan biodata serta hasil observasi awal. Pelatihan dan intervensi melalui pendampingan memberikan peningkatan kemampuan kelompok Nelayan Distrik Maladum Mes berdasarkan hasil post test sebesar 79\% serta output pelatihan tercapai berupa semua mitra memiliki akun e-mail, akun social media, dan akun video conference.
\end{abstract}

Kata kunci: Sistem Informasi, Zoom Meeting, Nelayan, SDM

\section{PENDAHULUAN}

Teknologi sistem informasi berkembang begitu cepat dengan waktu yang tidak dapat diprediksi dan tanpa batas. Teranyar, Era industri 4.0 mengarahkan otomatisasi industri dengan digitalisasi yang digagas oleh Jerman pada Hannover Fair Tahun 2011 telah menginspirasi berbagai negara untuk berlomba-lomba menerapkannya sehingga dapat bersaing secara global. Industri 4.0 sendiri merupakan kecanggihan teknologi yang dipadukan dengan otomatisasi, mempengaruhi proses produksi di berbagai bidang (Hadi \& Ardhi Khairi, 2020). Bukan hanya itu, Industri 4.0 mampu memberikan solusi dan kemudahan serta mengefisienkan dan mengefektifkan segala urusan, terlebih digitalisasi tidak lagi membatasi ruang dan waktu.

Perkembangan sistem informasi menjadi digitalisasi ini mentranformasikan peradaban manusia (Setiawan, 2017). Pola kerja yang semula konvensional dan interaksi sosial yang tradisional mengalami banyak perubahan, manusia bekerja lebih fleksibel dan terkoneksi tanpa batas. Semua sedang terjadi di semua profesi dan kelompok masyarakat di belahan dunia. Digitalisasi juga mengubah banyak hal, termasuk peningkatan kesejahteraan karena mampu mengakses sumber-sumber informasi yang tanpa batas menjadi media untuk meningkatkan kesejahteraan dan kemandirian. 
Nelayan sebagai bagian dari kelompok masyarakat yang berperan dalam menyediakan sumber protein hewani, juga menjadi penyerap banyak tenaga kerja serta selah satu alternative pengentasan kemiskinan (Shigueto et al., 2010), belum mendapat perhatian dalam meningkatkan kemandirian dan kesejahteraan. Selain itu juga, profesi penuh risiko dan mulia ini masih terabaikan. Kemiskinan masih mewarnai kelompok masyarakat yang berdiam di wilayah pesisir ini sehingga sentuhan tangan pemerintah dirasa perlu untuk meningkatkan produktivitasnya. Terlebih saat pandemi Covid-19 nelayan rentan berkurang produktivitasnya dikarenakan terhambatnya rantai pasok hasil perikanan untuk didistribusikan. Begitu juga masa new normal tidak menjamin adanya peningkatan jika tidak ada sentuhan untuk dapat meningkatkan produktivitasnya.

Distrik Maladum Mes merupakan distrik pemekaran dari distrik Sorong Barat dengan jumlah kelurahan sebanyak 4 kelurahan berpenduduk 8.424 Jiwa (www.sorong.bps.go.id, 2020). Wilayah yang berada di pinggiran kota Sorong memiliki lahan yang subur dan eksotis ini terletak sepanjang pesisir pantai utara kota Sorong. Penduduk yang memanfaatkan hasil perikanan sebagai mata pencaharian sebanyak 570 Orang (www.sorong.bps.go.id, 2017). Nelayan yang tinggal diwilayah ini rata-rata berpendidikan SLTP serta menggunakan alat tangkap handline. Wilayah ini juga mempunyai permasalahan dalam terbatasnya transportasi, mengingat distrik Maladum Mes adalah distrik terjauh dari pusat kota Sorong, sehingga ada keterbatasan jalur transportasi dan distribusi.

Politeknik Kelautan dan Perikanan Sorong sebagai perguruan tinggi vokasi bidang Kelautan dan Perikanan mempunyai tanggung jawab untuk memberikan pelayanan dharma pengabdian masyarakat kepada nelayan dalam menciptakan nelayan mandiri dan sejahtera. Survey pendahuluan yang dilakukan oleh panitia pengabdian masyarakat bersama penyuluh perikanan kota Sorong menemukan banyak nelayan belum memahami teknologi sistem informasi, terlebih digitalisasi, akibatnya nelayan mempunyai keterbatasan mengakses pengetahuan-pengetahuan baru untuk dapat meningkatkan kesejahteraannya. Era digital menjadi sesuatu yang tidak dapat dihindarkan lagi bagi semua pekerjaan termasuk nelayan, apalagi adanya Covid-19 dan masa new normal menguatkan betapa pentingnya pengetahuan teknologi sistem informasi .

Menginspirasi nelayan Inggris jual hasil tangkapan memanfaatkan group facebook "Jersey Alternatif Fish Market" (Kompas.com, 1 Mei 2020), terlebih wilayah Tempat Pelelangan Ikan Kota Sorong menjadi zona merah wabah Covid-19 (rmol.papua.id, 28 Mei 2020), tentunya akan menyulitkan transaksi jual beli ikan ditempat tersebut. berdasarkan hal tersebut, Politeknik Kelautan dan Perikanan Sorong memperkenalkan teknologi informasi berupa pembuatan email, pengenalan facebook, akses situs jual beli, dan pengenalan zoom cloud meeting. Pengenalan aplikasi tersebut berikut praktik penggunaannya dimaksudkan untuk menggiring nelayan memiliki kemampuan mengakses informasi untuk dapat melakukan jual beli maupun mendapatkan informasi seputar perikanan. Disamping itu hasil penelitian (Setriwati et al., 2018) memberi hasil berupa adanya kemudahan bagi nelayan mempromosikan hasil tangkapannya melalui media sosial. Sejalan dengan penelitian (Asirin \& Argo, 2017) pengembangan kapasitas nelayan menggunakan TIK yang inovatif bermanfaat untuk ketangguhan mata pencaharian nelayan.

\section{METODE}

Penyampaian materi kepada peserta pengabdian masyarakat dilakukan dengan metode ceramah baik secara konvensional melalui tatap muka maupun media digital Zoom Cloud Meeting yang dipandu oleh panitia. Materi pengabdian kepada masyarakat yang disampaikan adalah peran teknologi sistem informasi bagi manusia dan cara menggunakan teknologi informasi dalam dunia perikanan disaat pandemi Covid-19. Materi disampaikan oleh narasumber dipadukan dengan konten video peraga serta tanya jawab sebagai pendalaman materi dan mengeksporer pemahaman peserta terhadap materi yang disampaikan. 
Program pengabdian masyarakat ini dilakukan dengan tahapan sebagai berikut:

1. Observasi awal, tujuan observasi untuk memberikan gambaran awal kondisi peserta pengabdian masyarakat dan penggalian kebutuhan pelatihan bagi peserta pengabdian masyarakat.

2. Preetest dan tanya jawab terkait materi sebelum acara dimulai, khusus pretest tim pengabdian masyarakat hanya mempersiapkan pretest Zoom Cloud Meeting.

3. Peserta pengabdian kepada masyarakat diberikan motivasi peran teknologi sistem informasi bagi nelayan akan memberikan kemudahan dalam menjalani aktivitas pekerjaan.

4. Peserta pengabdian kepada masyarakat dilakukan pendampingan praktik sesuai materi yang dibawakan oleh narasumber

5. Peserta diberikan konten pelatihan sehingga dapat memperdalam materi di rumah

6. Tim pengabdian kepada masyarakat melakukan pendampingan bagi peserta dengan mengunjungi peserta pengabdian kepada masyarakat di rumah peserta untuk mengetahui sejauh mana penyerapan materi sekaligus mengulang materi yang belum dipahami terutama penggunaan aplikasi.

7. Peserta diberikan post test untuk mengetahui peningkatan kemampuan menggunakan aplikasi teknologi informasi Zoom Cloud Meeting pada akhir pendampingan yang telah dilakukan.

\section{HASIL DAN PEMBAHASAN}

Pelaksanaan pengabdian masyarakat ini dirancang sesuai dengan kebutuhan mitra berdasarkan hasil survey kebutuhan yang telah dilaksanakan sebelumnya. Analisa kebutuhan dijabarkan dalam kegiatan sosialisasi dan pelatihan yang berlangsung selama 1 hari dan membutuhkan adanya pendampingan. Pendampingan diperlukan karena nelayan sulit untuk menjalankan program karena keterbatasan pengetahuan (Yenida \& Sumiarti, 2015), rendahnya tingkat pendidikan (Hamdani \& Wulandari, 2016), pendampingan selama 3 kali untuk mengoptimalkan hasil dan tujuan pengabdian masyarakat dapat tercapai.

Kegiatan pengabdian masyarakat dilaksanakan di Pantai Wisata Cika tanggal 16 Juni 2020 diikuti oleh 30 peserta dengan menggunakan protokol kesehatan. Panitia dan peserta diwajibkan untuk melakukan cuci tangan sebelum memasuki tempat kegiatan. Selanjutnya peserta melakukan registrasi untuk memperlancar pelaksanaan kegiatan sehingga peserta dapat dengan mudah untuk didata dan didampingi pada saat pelaksanaan sosialisasi, pelatihan,dan pendampingan.
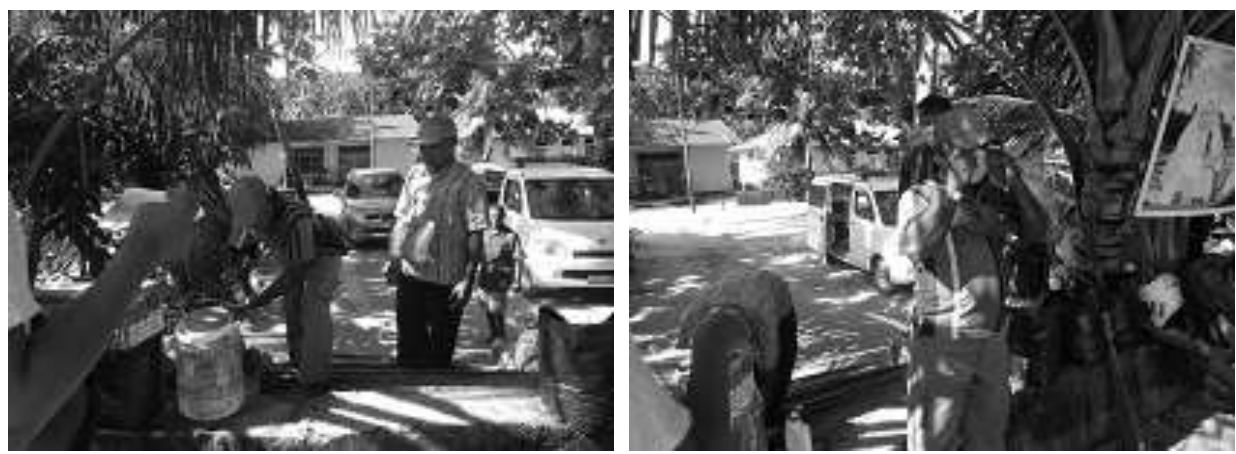

Gambar 1. Registrasi Peserta dengan Penerapan Protokol Kesehatan Sebelum Memasuki Lokasi Sosialisasi Pelatihan

Pelatihan yang efektif dan tepat sasaran merupakan tujuan yang diharapkan dalam setiap pelaksanaan pengabdian masyarakat. Analisa kebutuhan yang sudah ada sebelumnya harus dapat mencapai sasarannya. Untuk mencapai itu tim pengabdian masyarakat menyesuaikan daftar isian berupa biodata yang telah diberikan pada saat mendata peserta kegiatan pengabdian kepada 
masyarakat. Analisa kebutuhan yang telah diperoleh disinkronkan dengan pretest dan pertanyaan awal terhadap peserta pengabdian masyarakat. Pertanyaan yang disampaikan terkait materi yang akan dilatih diantaranya adalah :

1. Apakah peserta sudah memiliki akun email?

2. Apakah peserta sudah memiliki akun sosial media?

3. Apakah peserta sudah memiliki akun zoom?

Hasil pertanyaan awal didapat gambaran sebagat berikut :

Tabel 1. Hasil pertanyaan kepemilikan akun

\begin{tabular}{cccc}
\hline No. & Pertanyaan & Memiliki & Tidak Memiliki \\
\hline 1 & Akun E-mail & $20 \%$ & $80 \%$ \\
2 & Akun Sosial Media & $20 \%$ & $80 \%$ \\
3 & Akun Zoom Cloud Meeting & $10 \%$ & $90 \%$ \\
\hline
\end{tabular}

Tanya jawab ini untuk memudahkan pelatih dalam memberikan materi. Pretest juga diberikan terkait dengan Zoom Cloud Meeting sebagai bagian dari kelanjutan pengabdian masyarakat berikutnya memberikan materi melalui aplikasi zoom. Pretest zoom ini diberikan untuk melihat pemahaman peserta dalam materi yang akan disampaikan oleh narasumber.

Pembukaan pelatihan dimulai dengan laporan kegiatan yang disampaikan oleh ketua panitia. Rangkaian pembukaan dilanjutkan dengan sambutan direktur tentang pentingnya literasi digital untuk dapat meningkatkan produktivitas nelayan, terutama di era pandemi covid-19. Direktur juga sekaligus mensosialisasikan protokol kesehatan dalam upaya pencegahan covid-19 yang disampaikan melalui aplikasi zoom cloud meeting.
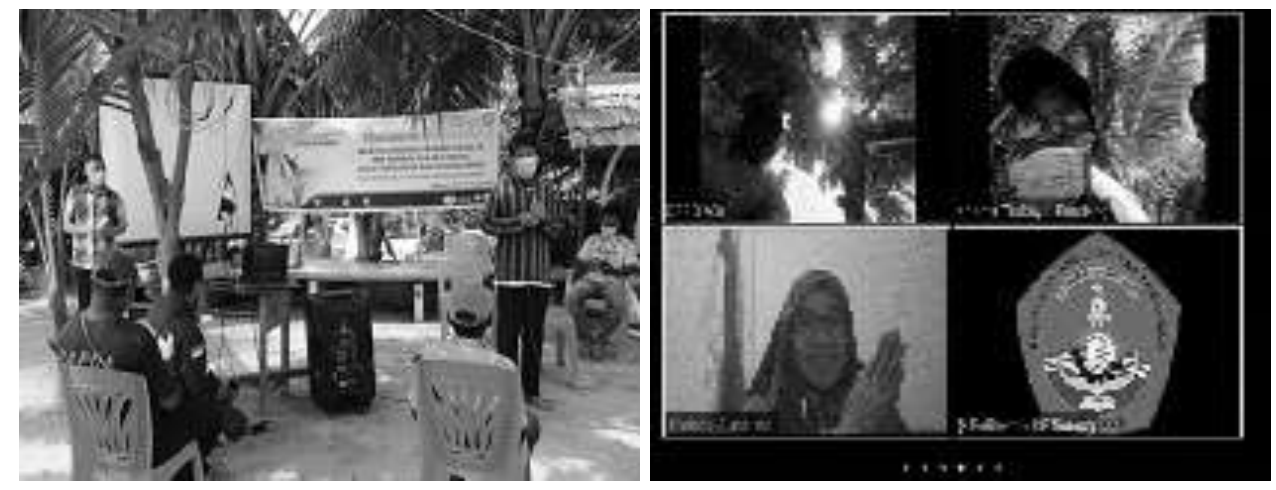

Gambar 2. Pembukaan : Laporan Ketua Panitia dan Pembukaan kegiatan oleh Direktur

Sesi materi pelatihan dimulai dengan pelatihan pembuatan electronic mail "Gmail”, sosial media "facebook" dan pengenalan aplikasi jual beli. Materi dipaparkan narasumber/dosen sekaligus dilakukan pembimbingan praktik oleh instruktur dan taruna/i. Pemateri memaparkan pentingnya memiliki akun e-mail, sosial media, aplikasi jual beli untuk dapat meningkatkan produktivitas usaha dalam jual beli hasil tangkap maupun aktivitas bersosialisasi. Akhir pemaparan, pemateri menyampaikan UU ITE yang penting dipahami untuk dapat mentaati peraturan dan hukum.

Materi selanjutnya merupakan materi pengenalan Zoom Cloud Meeting dan pelatihan membuat akun zoom. Pengenalan zoom ini dilakukan karena zoom merupakan aplikasi yang piawai dijadikan media pembelajaran daring dapat diandalkan (Naserly, 2020). Narasumber menyampaian era digital penting dapat menggunakan aplikasi digital Zoom Cloud Meeting untuk memudahkan transfer pengetahuan dan keterampilan. Pembuatan akun zoom dipaparkan oleh 
narasumber dengan menggunakan konten video sehingga dapat lebih memudahkan peserta memahami dan dibantu oleh instruktur serta taruna/i dalam praktiknya.

Materi-materi pelatihan yang dipaparkan oleh Narasumber diberikan kepada peserta untuk dapat memahami lebih mendalam terkait materi yang diberikan dan memudahkan tim dalam melakukan pendampingan. Tahapan sosialisasi dan pelatihan diakhiri dengan foto Bersama peserta dan tim pengabdian masyarakat.

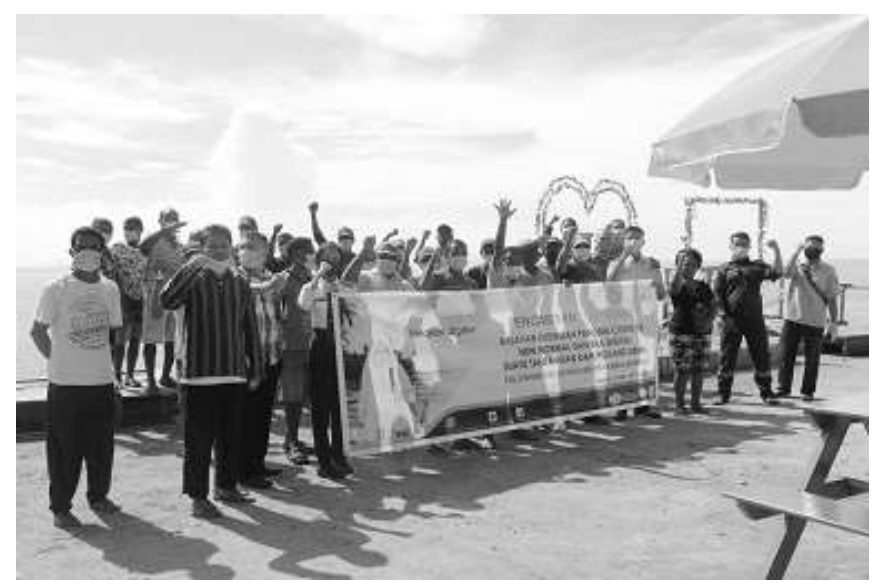

Gambar 3. Foto Bersama diakhir Sesi Pelatihan

Nelayan peserta pengabdian masyarakat yang diperkenalkan sistem informasi berupa email, facebook, situs jual beli, dan zoom cloud meeting rata-rata berpendidikan SMP sehingga tingkat pemahaman terhadap sistem informasi masih rendah. Pertanyaan-pertanyaan pretest yang diajukan sesaat sebelum pelaksanaan kegiatan dibuka maupun hasil Tanya jawab yang dilakukan oleh tim saat memberikan praktik menjadi tolak ukur kemampuan awal. Hasil pretest disajikan sebagai berikut :

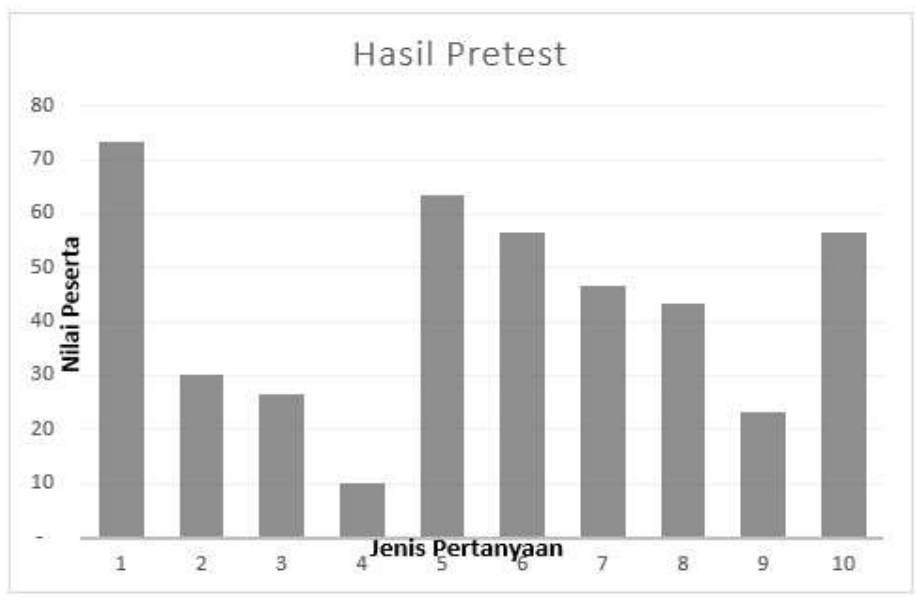

Gambar 4. Hasil Pretest Zoom Cloud meeting sebelum pelatihan

\section{Pendampingan Pascapelatihan}

Hasil pretest menjadi acuan dalam pendampingan pascapelatihan, alat komunikasi juga menjadi kendala dalam pelatihan karena tidak semua nelayan memiliki hp android dan bantuan Handphone yang diberikan terbatas kepada ketua kelompok. Disamping itu, selama ini nelayan tersebut jarang menggunakan TIK dalam berkomunikasi, sejalan dengan (Trisnani, 2016) nelayan belum banyak menggunakan teknologi informasi karena tidak mempunyai ketrampilan dibidang TIK. Pendampingan lebih intensif menjadi penting sehingga tujuan pengabdian masyarakat 
tercapai. Pendampingan dilakukan secara terjadwal dengan mengunjungi rumah ketua kelompok nelayan maupun dengan media komunikasi dan melakukan coaching langsung proses pembuatan email, pembuatan facebook, maupun pembuatan akun zoom beserta cara pengunaannya. Pendampingan dilakukan berkoordinasi dengan penyuluh perikanan wilayah
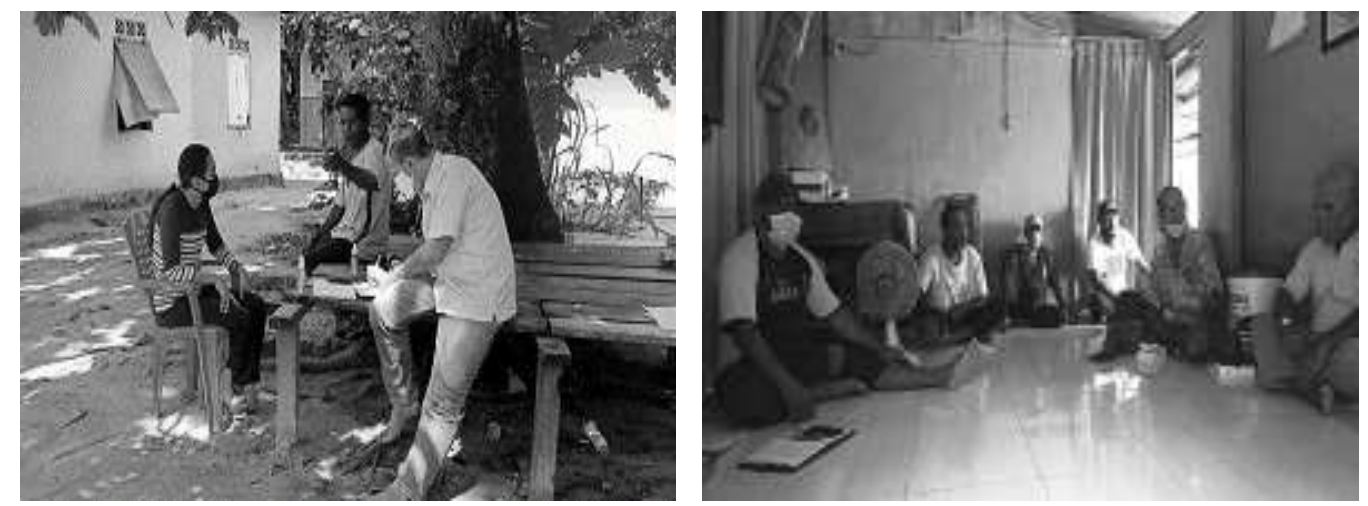

Gambar 5. Pendampingan Individu maupun kelompok

Hasil pendampingan pertama peserta seluruhnya memiliki akun email Gmail, hasil pendampingan kedua peserta seluruhnya memiliki akun sosial media facebook, dan hasil pendampingan ketiga peserta seluruhnya memiliki akun zoom. Hasil pendampingan dapat dilihat pada gambar berikut :

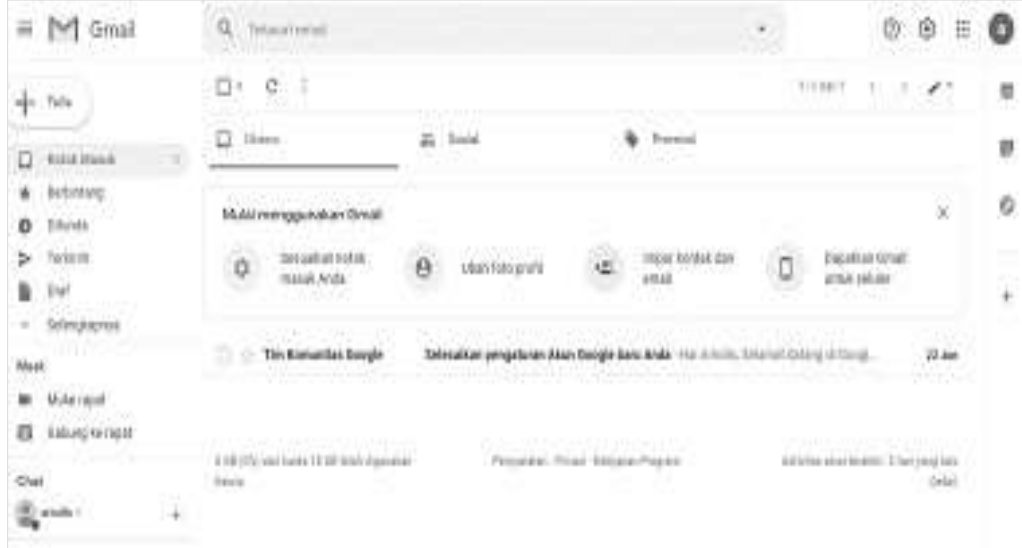

Gambar 6. Akun GMail Peserta Pengabdian Masyarakat

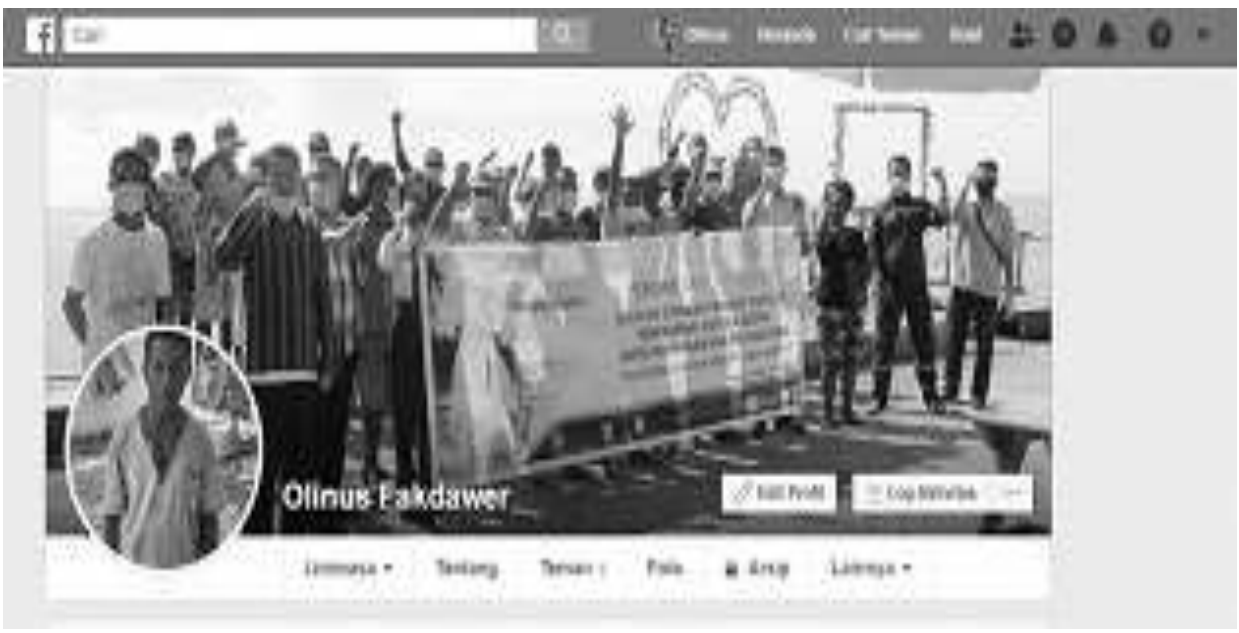

Gambar 7. Akun Facebook Peserta Pengabdian Masyarakat 


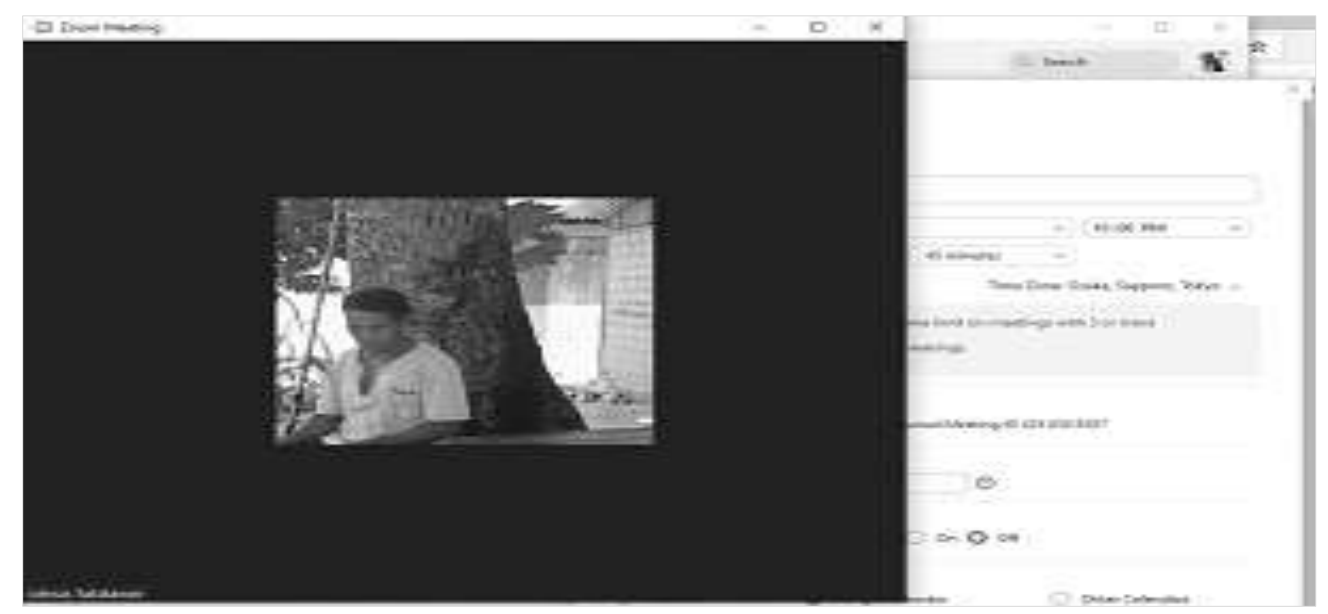

Gambar 8. Akun Zoom Cloud Meeting peserta Pengabdian Masyarakat

Pendampingan yang diberikan selama 3 kali tergambar dari pencapaian output pada tabel. 2 berikut ini :

Tabel 2. Output hasil pendampingan

\begin{tabular}{cccc}
\hline No. & Output & Memiliki & Tidak Memiliki \\
\hline 1 & Akun E-mail & $100 \%$ & $0 \%$ \\
2 & Akun Sosial Media & $100 \%$ & $0 \%$ \\
3 & Akun Zoom Cloud Meeting & $100 \%$ & $0 \%$ \\
\hline
\end{tabular}

Sesi akhir dari pendampingan peserta pengabdian masyarakat diberikan post test untuk melihat hasil pendampingan yang dilakukan selama 3 kali.

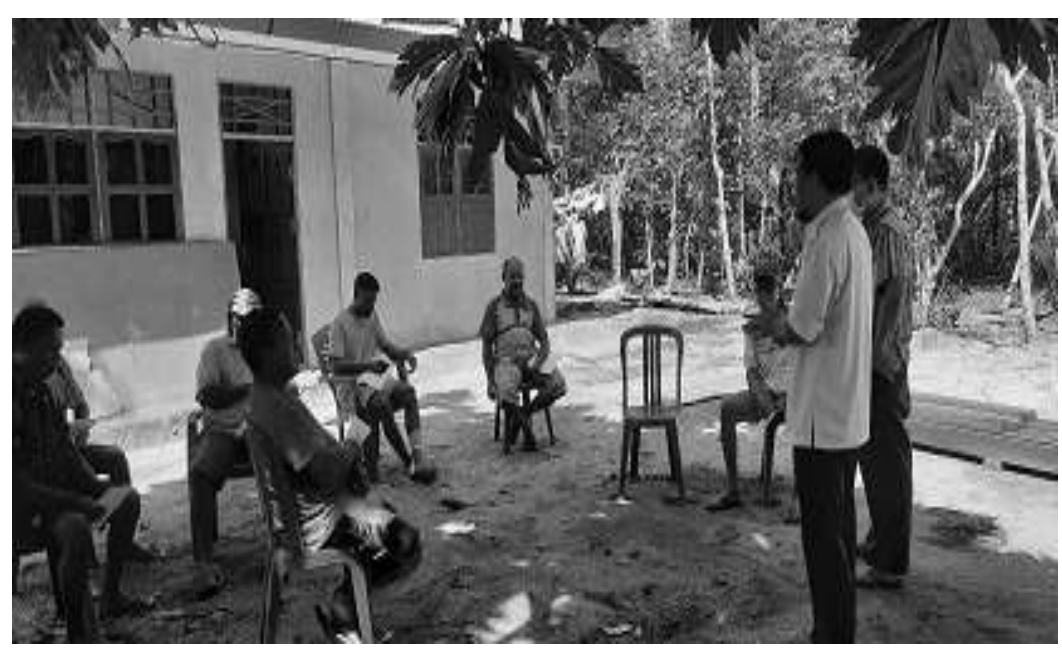

Gambar 9. Pemberian Posttest di Akhir Kegiatan Pendampingan Pengabdian Masyarakat.

Perbandingan hasil pretest dengan hasil posttest dapat dilihat pada gambar berikut : 


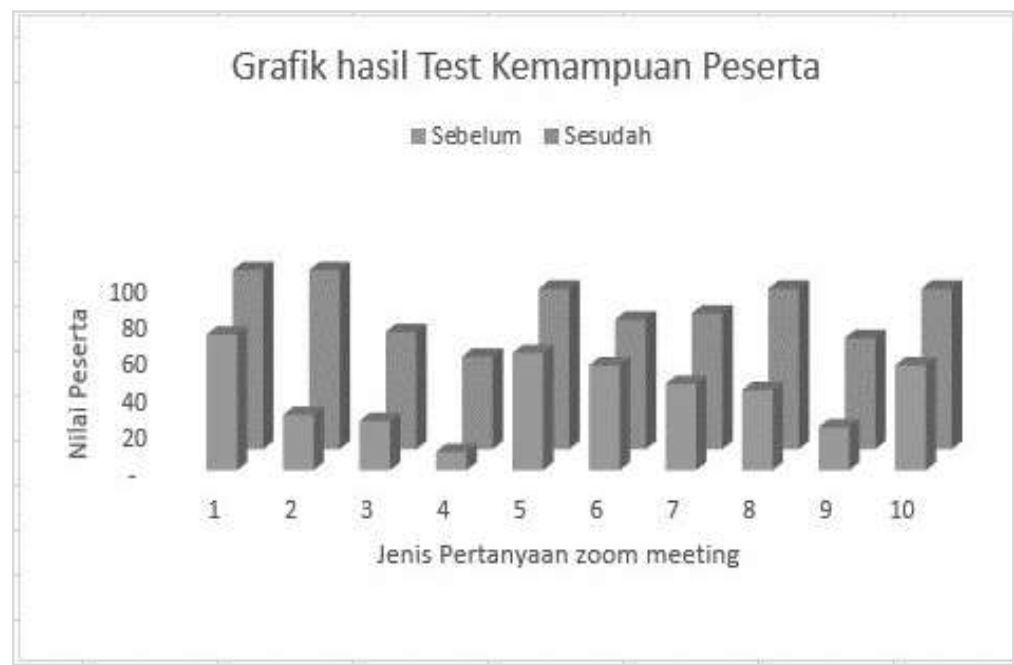

Gambar 10. Hasil test kemampuan pretest dan posttest kegiatan pengabdian.

Hasil postest menunjukkan ada kenaikan pemahaman dari peserta pengabdian masyarakat dalam menggunakan aplikasi zoom cloud meeting. Grafik menunjukkan kenaikan rata-rata kemampuan dalam menggunakan aplikasi zoom cloud meeting sebesar $79 \%$ dengan adanya intervensi pendampingan.

\section{KESIMPULAN}

Teknologi Informasi bukan lagi menjadi barang baru dalam kehidupan manusia. Keduanya bersanding saling memberi pengaruh untuk perkembangan dunia. Dampaknya merubah kualitas kehidupan manusia tanpa memandang status pekerjaan, waktu dan sekat geografis. Nelayan sebagai salah satu profesi juga berdampak atas kemajuan teknologi informasi ini. Faktor yang menghambat nelayan untuk dapat mengakses teknologi informasi adalah faktor SDM (Takariani, 2015); (Yenida \& Sumiarti, 2015). Hasil pretest dan pertanyaan yang diajukan memberikan bukti atas rendahnya SDM nelayan.

Pengabdian masyarakat yang dilakukan sudah mencapai sasaran dan tujuan dengan memberi dampak positif bagi peningkatan kapasitas nelayan. Intervensi berupa pendampingan memberi peningkatan pemahaman terhadap teknologi informasi dan komunikasi sebesar 79\% dan nelayan sudah dapat dikatakan menuju melek digital karena sudah memiliki akun e-mail "Gmail", social media "Facebook", dan video conference "Zoom Cloud Meeting".

\section{SARAN}

Hasil temuan pada kegiatan pelatihan dan pendampingan pengabdian masyarakat kelompok nelayan distrik Maladum Mes dapat diberikan saran :

1. Kegiatan pengabdian masyarakat selanjutnya dapat dilakukan transfer pengetahuan menggunakan aplikasi video conference sehingga mengefisienkan waktu dan biaya dan kelompok mitra perlu pengulangan untuk lebih melek digital;

2. Output pengabdian masyarakat dapat dijadikan media penyuluhan baik dari penyuluh maupun pemangku kepentingan lain.

3. Akses teknologi sistem informasi perlu ditingkatkan di wilayah-wilayah jauh dari pusat kota sebagai bagian dari pemerataan pembangunan dan akses informasi. 


\section{UCAPAN TERIMA KASIH}

Ucapan terima kasih penulis sampaikan kepada Direktur Politeknik KP Sorong atas dukungan anggaran sehingga pengabdian masyarakat dapat terlaksana dengan baik, Pembantu Direktur I Bidang Akademik atas masukan yang konstruktif sehingga pengabdian masyarakat difokuskan di wilayah terdekat dengan kampus dan kelompok masyarakat yang terdampak Covid-19. Kepala Balai Riset Observasi Laut Bali atas bantuan alat komunikasi, Pimpinan Telkomsel Cabang Sorong atas pemberian kartu perdana, Kepala distrik Maladum Mes, Lurah Tanjung Kasuari, Lurah Tanjung Saoka atas fasilitasi kegiatan, Penyuluh Perikanan Kota Sorong atas koordinasi dalam pelaksanaan kegiatan, serta Muhammad Rizky atas support terhadap konten video.

\section{DAFTAR PUSTAKA}

Asirin, A., \& Argo, T. A. (2017). Penggunaan Teknologi Informasi dan Komunikasi dan Implikasinya terhadap Ketangguhan Mata Pencaharian Nelayan. Journal of Regional and Rural Development Planning, 1(1), 1. https://doi.org/10.29244/jp2wd.2017.1.1.1-15

Hadi, A. S., \& Ardhi Khairi. (2020). Pemilihan Strategi Pemasaran Di Era Digital Pada Kelompok Ibu Pkk Desa Gadingharjo. Dinamisia : Jurnal Pengabdian Kepada Masyarakat, 4(1), 127-132. https://doi.org/10.31849/dinamisia.v4i1.3246

Hamdani, H., \& Wulandari, K. (2016). Faktor Penyebab Kemiskinan Nelayan Tradisional ( The Factor of Poverty Causes Traditional Fisherman ). E-Sospol, 3(April), 61-67.

Naserly, M. K. (2020). Implementasi Zoom, Google ClassRoom, dan Whatsapp Group dalam Mendukung Pembelajaran Daring (Online) Pada Mata Kuliah Bahasa Inggris Lanjut (Studi Kasus Pada 2 Kelas Semester 2, Jurusan Administrasi Bisnis, Universitas Bina Sarana Informatika Jakarta). Journal of Chemical Information and Modeling.

Setiawan, W. (2017). Era Digital dan Tantangannya. Seminar Nasional Pendidikan 2017, 1-9. https://core.ac.uk/download/pdf/87779963.pdf

Setriwati, B., Suryaningsih, S., \& Solina, E. (2018). 1, 2 3. 1-9.

Shigueto, A., Mangel, J., Pajuelo, J., Dutton, P., Seminoff, J., \& Godley, B. (2010). Fisheries Research. Fisheries Research, 106, 8-17.

Sorong, B. P. S. K. (2017). Distrik Maladomes dalam Angka. BPS Kota Sorong. https://sorongkota.bps.go.id/publication/2017/09/20/eb7d6c41fd26ba2767348f15/distri k-maladomes-dalam-angka-2017.html

Sorong, B. P. S. K. (2020b). Statistik Daerah Kota Sorong (Issue 1). https://sorongkota.bps.go.id

Takariani, C. S. D. (2015). Opini Nelayan Tentang Akses Informasi Publik. Jurnal Penelitian Komunikasi, 18(2), 101-114. https://doi.org/10.20422/jpk.v18i2.40

Trisnani. (2016). Pola Komunikasi Masyarakat Nelayan di Era Teknologi Informasi. Penelitian Komunikasi Dan Opini Publik, 20(2), 141-154.

Yenida, Y., \& Sumiarti, E. (2015). Karakteristik Geografis dan Kondisi Masyarakat dan Kondisi Masyarakat Miskin (Nelayan) di Wilayah Pesisir Pantai Sumatera. Jurnal Poli Bisnis, 7(2). 